\title{
Border Policing Challenges and the Consequences of Transnational Organised Street begging in Nigeria
}

\section{Usman Adekunle Ojedokun}

Department of Sociology

University of Ibadan, Ibadan, Nigeria

DOI:10.36108/NJSA/8102/61(0210)

\begin{abstract}
Illegal border-crossing is a major problem confronting many nations. In Nigeria, the security of land borders is constantly put to test by the influx of transnational organised street beggars. Against this background, this study examined border policing challenges and the consequences of transnational organised street begging in Nigeria. The study was exploratory and cross-sectional in design. The situational crime prevention perspective was adopted as theoretical guide. The key informant interview method was primarily utilised to elicit data from personnel of five relevant law enforcement agencies. Findings revealed that the challenges at controlling illegal entry of transnational organised street beggars are multi-dimensional. Crime perpetrations and involvement in insurgency are among the major ways through which transnational organised street beggars threaten Nigeria. The Federal Government of Nigeria is urged to develop necessary mechanisms through which relevant law enforcement agencies can be made more effective at policing the borders and enforcing migration laws.
\end{abstract}

Keywords: Border policing, land borders, transnational organised street beggars, migration laws, Nigeria

\section{Introduction}

Illegal border-crossing is among the major challenges confronting several countries in Africa (Addo, 2006; Blum, 2014). The violation of international migration laws by illegal migrants, traffickers and smugglers are a daily event shared by most African countries (African Union, 2012). The pervasiveness and potency of border insecurity in the continent has informed the formulation of different international resolutions and protocols, such as the African Common Position on Migration and Development, the Migration Policy Framework for Africa, the Ouagadougou Action Plan to Combat Trafficking in Human Beings, the Kampala Declaration and Recommendations on Refugees, Returnees and Internally Displaced Persons amongst others. However, despite these attempts at sub-regional and international cooperation, criminal crossborder activities still constitute a key variable of instability (Blum, 2014).

The phenomenon of street begging is fast assuming an international dimension as street beggars are increasingly realising the potential profitability of moving from one country to another for the purpose of alms solicitation (Invernizzi, 2011; Delap, 2009; International Organisation for Migration, 2004). Consequently, while an increasing number of Nigerian street beggars 
are travelling out of the country to solicit alms in some more economically developed countries such as Saudi Arabia, Turkey, and United Arab Emirates (Punch, 2012; Adewuyi, 2000), the security of the Nigerian land borders is constantly being put to test by the influx of transnational organised street beggars from some neighbouring West African countries (Igbinovia, 1991; Adedokun, 2003; Adedibu \& Jelili, 2012; Salami \& Olugbayo, 2013; Ojedokun $\&$ Aderinto, 2015). The endemic nature of street begging in Nigeria and its negative implications over time cannot be overemphasised. The recognition of this deviant behaviour as a serious social problem has compelled the Federal Government of Nigeria and some State Governors to formulate measures to contain it at different points in time. The problem has, however, remained pervasive despite past efforts designed to address it (Adewuyi, 2000; Adedibu and Jelili, 2011; Aboluwade, 2012; Balogun, 2012).

Transnational organised street beggars are not only contributing to the problem of street begging, their unrestricted inflow is capable of impacting negatively on the socio-political security of Nigeria. Apart from the fact that cross-border and immigration crime is often highly organised and generates large profits for the criminals involved while causing untold harm on individuals and communities (UK Border Agency, 2010), the global rise in terrorist threats and transnational criminal activities has also been linked to border management issues (Lamptey, 2013). Indeed, some immigrants from some neighbouring African countries have been indicted by law enforcement officials as members of the Boko Haram insurgent group (Adepegba, 2012; Okoli, 2013; Alli, 2016; Kayode, 2017). Furthermore, studies have equally established a relationship between organised human trafficking network and immigrants' involvement in street begging (Cherneva, 2011; Delap, 2009; Social Development Notes, 2009; Friends-International and United Nations Inter-Agency Project, 2006). Although illegal immigrants may enter a country on their own, nevertheless, they often need the assistance of professional smugglers to clandestinely facilitate their movements to their desired destination (Väyrynen, 2003).

Illegal and clandestine movements of people across national borders cannot be separated from government control and law enforcement (Väyrynen, 2003). On his part, Okumu (2009) contends that African countries are increasingly facing daunting tasks of managing their borders in ways that will secure their territorial sovereignty/integrity, ensure that they are bridges rather than barriers for cross-border cooperation and regional integration, and prevent illegal entry of people. Similarly, Blum (2014) posits that transnational syndicates have been operating in the West African sub-region since the 1960s. Furthermore, Adetula (2015) states that Nigeria is a major receptor of undocumented migrants. In addition, the West African Network for Peace-building (2013) observes that Nigeria's poor border control towards Niger Republic, Chad Republic and Cameroon makes smuggling of goods and humans relatively easy. Moreover, Miller (2001) claims that illegal immigration, human smuggling, and trafficking are interrelated and result in a 'terrible paradox'. 
Moreover, Väyrynen (2003) maintains that countries that have lax immigration laws and small penalties for illegal immigrants and their traffickers usually become popular targets and way stations for them.

Border security management approach capable of promoting national security has generally been given low priority in Africa (Okumu, 2009). The magnitudes, severities and complexities of border management problems in the continent calls for urgent actions to turn borders into zones of peace, security, stability and development (African Union, 2012). Despite the fact that studies have examined problems of illegal movements, human smuggling and human trafficking across the Nigerian borders (Adeyinka, 2014; Blum, 2014; Adetula, 2015), sufficient scholarly attention has not been devoted to border policing challenges and consequences of transnational organised street begging in Nigeria. Hence, this study was conceived to bridge this gap.

\section{Theoretical Framework}

This study was anchored on situational crime prevention theory by Ronald Clarke. This perspective focuses on how crime can be prevented by changing the situational or spatial features present in an environment. It involves the development of techniques to prevent, constrain or disrupt criminal activity. According to Clarke (1992), these techniques use a variety of environmental manipulations to alter the risks, efforts, and rewards of offending. The foundation of this theory relies on the assumptions that more opportunities lead to more crime, easier ones attract more offenders, and the existence of easy opportunities makes possible for a "life of crime". Specifically, the situational crime prevention theory opines that society plays a role in inadvertently creating crime through the manufacturing of "criminogenic goods", through leaky systems, and poor management/design of facilities. Society thus needs to come up with new ideas with lesser economic and social costs. Therefore, situational crime prevention involves measures directed at highly specific forms of crime that involve the management, design or manipulation of the immediate environment in a systematic and permanent way (Clarke, 1983). Essentially, four major strategies namely, target hardening, access control, deflecting offenders, and controlling facilitators are necessary for crime prevention. The theory opined that crime can be reduced effectively by altering situations rather than an offender's personal dispositions. It introduces discrete managerial and environmental change to reduce the opportunity for crimes to occur ... it seeks not to eliminate criminal or delinquent tendencies through improvement of society or its institutions, but merely to make criminal action less attractive to offenders (Clarke, 1992). A major way through which relevant law enforcement agencies charged with the responsibility of maintaining law and order at border stations in Nigeria can be more effective is to change their border management strategies and approaches by developing innovative ideas 
through which environmental and situational factors aiding illegal entry of transnational organised street beggars into Nigeria can be contained.

\section{Research Setting and Study Population}

This study was conducted among the officials of five relevant government agencies including, the Nigeria Immigration Service, the Nigeria Custom Service, the Nigeria Police, Oyo State Ministry of Women Affairs, Community Development and Social Welfare, and the National Agency for the Prohibition of Trafficking in Persons and Other Related Matters (NAPTIP). These law enforcement agencies and government ministry were strategically selected. Their constitutionally-prescribed mandates enabled them to have first-hand information on the migration process of transnational organised street beggars, the relationship between transnational organised street begging and human trafficking, as well as the negative effects of transnational organised street begging on Nigeria. In addition, the zonal headquarters of these agencies located in Lagos and Ibadan metropolis were essentially targeted because of the large number of transnational organised street beggars soliciting alms in the two cities.

\section{Methods}

The study was exploratory and cross-sectional in design. Data were principally generated through the key informant interview method. Seven key personnel of relevant government agencies, who have considerable field experience and expert knowledge on the areas of migrants-flow, illegal migration, law enforcement, border policing and street begging in Nigeria were purposively selected. The respondents included three Assistant Area Comptrollers of the Nigeria Immigration Service of the zone ' $F$ ' headquarters in Ibadan, one Assistant Customs Area Controller of the Oyo/Osun area command in Ibadan, one principal officer of the Oyo State Ministry of Women Affairs, Community Development and Social Welfare, Ibadan, one Zonal Commander of the National Agency for the Prohibition of Trafficking in Persons and other Related Matters (NAPTIP), Lagos, and one Assistant Superintendent of Police of Sango Divisional Police Station, Ibadan. Data were collected with the aid of a tape-recorder and a field note. Furthermore, the data generated were content analysed using the narrative technique of reporting and ethnographic summaries. This involved a careful transcription, detailed description and interpretation of the tape-recorded data and field-note. All categories of responses were compared and merged to draw out and/or create a clear picture of the emerging themes to further enhance the robustness of the findings interpretations.

\section{Results and Discussion}

This section discusses the results that emanated from the two major objectives covered in this study. The findings were thematically presented as a way of ensuring logicality and lucidity of discourse. 


\section{Challenges at Controlling the Influx of Transnational Organised Street Beggars into Nigeria}

Since some government agencies in Nigeria are constitutionally mandated to combat illegal entry and enforce anti-street begging law, it was considered imperative to understand the situational and environmental factors inhibiting efforts at controlling activities of transnational organised street beggars. Different challenges, both institutional and non-institutional, were mentioned by the respondents. A major challenge identified was the porous nature of the Nigerian borders. The key informants opined that transnational organised street beggars easily gained entry into Nigeria as a result of the porous state of most of the nation's land borders. A key informant captured the situation this way:

In the Northern part of the country, anywhere goes in the dry season. Even Immigration and Custom officers cannot effectively control illegal movement of people into Nigeria at the border stations. You only stay at your duty post to carry out your statutory duties. (Custom Officer/KII/ Oyo/Osun Area Command, Ibadan)

Another key informant stated:

According to our records, most of them (transnational organised street beggars) came into the country through what is called illegal routes. The Nigerian borders are not fenced; we have porous borders. There are 147 recognised border-posts in Nigeria but because of the nature of our environment, it is difficult to control them. For instance, in the areas of arid desert, everywhere is open. They (transnational organised street beggars) do not pass through appropriate border posts, because they do not have valid documents, passport, travelling certificate or what is known as L'cest Visae in French language. (Immigration Officer/KII/Zone ' $F$ ' Headquarter, Ibadan)

It can be deduced from these statements that the spatial arrangement and topographical landscape of some parts of Nigeria, particularly in the North, are contributing to the porous nature of some of the Nigerian borders, thereby aiding illegal immigration and the influx of transnational organised street beggars into Nigeria. Despite the fact that a total of 147 borders are officially recognised in Nigeria, there are some other unknown points of entry being used by illegal migrants, including transnational organised street beggars Igbinovia (1991). Recently, the Nigeria Immigration Service declared that it uncovered about 1,487 illegal routes into the country (Adepegba, 2013; Vanguard, 2013). This finding demonstrates the relevance of situational crime prevention theory which opines that more opportunities lead to more crime, easier ones attract 
more offenders, and the existence of easy opportunities makes possible for a "life of crime".

Another major challenge that was mentioned was the problem posed by the Economic Community of West African States (ECOWAS) policy on free movement of citizens of West African countries in the sub-region, to which Nigeria is a signatory. According to one of the provisions contained in Article 3 of the ECOWAS protocol ratified in 1980: "A citizen of the community visiting any member state for a period not exceeding 90 days shall enter the territory point free of visa requirements. Such citizen shall, however, be required to obtain permission for an extension of stay from the appropriate authority if after such entry that citizen has a cause to stay for more than (90) days" (Afolayan, 1988: 5).

One of the key informants described the situation this way:

The ECOWAS policy tends to reduce border lines across the West African sub-region to such an extent that there is little check at our borders; and consequently, this gives room for easy movement of people from one country to another across the subregion. (Police Officer/KII/Sango Police Station, Ibadan)

Another key informant stated thus:

The Nigerian Government is always cautious in going about this issue because they do not want to be seen as going against the ECOWAS treaty because of Nigerians living in other countries. They may also retaliate against our people living in their country. (Immigration Officer/KII/Zone ' $F$ ' Headquarter, Ibadan)

These narratives indicate that some transnational street beggars capitalised on the ECOWAS policy which has greatly reduced entry limitations among nations of West African countries. Although this policy was essentially formulated to promote strong socio-political and economic ties among the countries, some individuals with ulterior motives, in this context, transnational organised street beggars, are however also exploiting the opportunity to further their own goals. This finding validates a major proposition of the situational crime prevention theory which states that society plays a role in inadvertently creating crime, through the manufacturing of "criminogenic goods", through leaky systems, and poor management/design of facilities. In addition, Blum (2014) has equally noted that transnational organised crime has increased in West Africa simultaneously with the growing commitment towards free movement of persons and goods as enshrined in the ECOWAS Policy.

The lack of statutory empowerment conferring authority on relevant government agencies to tackle transnational organised street begging was another key challenge that was also mentioned by nearly all the respondents. According to one of the key informants: 
Statutorily, our ministry is not empowered to deal with the issue of transnational street beggars. However, recognising our limitation, we have a good working relationship with the Nigeria Immigration Service regarding information sharing and the designing of action plans. (Principal Officer/KII/Oyo State Ministry of Women Affairs, Community Development and Social Welfare)

In the words of another respondent:

The control of transnational street beggars does not fall directly on the Nigeria Police. Our mandate does not cover street begging in general, because it is a social problem that is best tackled by state governments. (Police Officer/KII/Sango Police Station, Ibadan)

Another respondent stated:

This agency does not directly deal with the problem of street begging and street beggars, but we are particularly concerned with human trafficking victims. It is when it is exploitatively done in such a way that some individuals are living off the earnings of beggars that we have the authority to intervene. (NAPTIP Official/KII/Lagos Zone Command)

From the above, it is obvious that, apart from the officials of the Nigeria Immigration Service that are concerned with preventing illegal entry of people into Nigeria, other relevant government agencies did not view transnational street begging as falling within the ambit of their mandates. However, these submissions of the key informants is surprising given that street begging is generally proscribed as indicated in sections 249 and 250 of the Criminal Code of 1958 and section (21e) of the 1963 federal constitution of Nigeria. In fact, many States in Nigeria have recently passed anti-street begging bill into law (Abdullahi, 2016; Muhammed, 2016). The implication of this finding is that the problem of transnational organised street begging in Nigeria is not being given adequate attention by relevant government ministry and law enforcement agencies.

Furthermore, the common language which some of the transnational organised street beggars shared with the Hausas of northern Nigeria was identified by some of the key informants as one of the main challenges militating against their control. A key informant had this to say:

Most of them took the advantage of the language which they commonly speak with the Hausas and Fulanis in the North especially in those villages that shared boundary with some neighbouring countries like Niger Republic and Chad Republic 
to gain entry into Nigeria and usually moved into the Southern part of the country. (Immigration Officer/KII/Zone ' $F$ ' Headquarter, Ibadan)

In the words of another immigration official:

Most of the transnational beggars here are Nigeriens; if one is not very careful they would tell one that they are from Sokoto State, and because of the Hausa language they speak, it takes somebody who is well trained to be able to differentiate them from the people of northern Nigeria. (Immigration Officer/ KII/Zone ' $F$ ' Headquarter, Ibadan)

The statement of this key informant shows that most of the transnational organised street beggars in Nigeria are nationals of Niger Republic who are mainly Hausa language speakers like the people of Northern Nigeria. This commonly spoken language is also posing a serious challenge to law enforcement officers at regulating their movement into the country because it is very difficult to distinguish between a native Hausa speaker and a nonNigerian speaker of the language. This finding corroborates the submission of Adetula (2015) that the transnational character of some West African languages and cultures has further complicated the problem of illegal migration. This finding equally brings to bear the relevance of one of the submissions of situational crime prevention theory which states that more opportunities lead to more crime, easier ones attract more offenders, and the existence of easy opportunities makes possible for a "life of crime".

The human trafficking networks that specialised in the illegal acts of conveying or smuggling people from one country to another operating across some countries in the West African sub-region and beyond was also mentioned as contributing to the challenges being encountered by law enforcement agents.

In the words of a key informant:

Of particular note is the human trafficking network in aiding illegal movements of people across our borders. However, the Nigeria Immigration Service is observing the connection between the two (street begging and transnational organised street begging) so as to effectively address the menace. (Immigration Officer/KII/Zone ' $F$ ' Headquarter, Ibadan)

Another key informant stated thus:

Human trafficking networks along the border line are aiding people for the purpose of engaging in some dehumanising jobs, including transnational street begging. The Nigeria Police do not condone this because it is a form of slavery. (Police Officer/ KII/Sango Police Station, Ibadan) 
Another also submitted:

For Lagos zone, we are closely studying the trend to confirm if children or any other persons are purposely brought to engage in street begging. However, we are currently looking into a reported case of a Nigerian girl who was trafficked to Libya for the purpose of alms solicitation. (NAPTIP Official/KII/Lagos Zonal Command)

From these submissions, it is clear that a close connection exists between human trafficking and transnational organised street begging in Nigeria. In addition, it can also be inferred from these findings that apart from the fact that people from other countries are being trafficked into Nigeria to engage in street begging, some Nigerians are also being trafficked abroad for the purpose of alms solicitation. A link between human trafficking networks and street begging had been established in studies conducted in different parts of the world (Annuska, 1998; International Organization for Migration, 2004; Azam, 2011; Cherneva, 2011).

\section{Consequences of Transnational Organised Street Begging in Nigeria}

Studies have established that street begging has negative effects on the society (Koselci, Rosati \& Tovo, 2007; Ogunkan \& Fawole, 2009; Mehak, 2012). Therefore, the negative impact of transnational organised street begging on Nigeria was investigated. Findings revealed that the influx of transnational organised street beggars poses multiple threats to Nigeria. All the respondents posited that their continual influx is capable of worsening the insecurity challenge in the country. Transnational organised street beggars were recognised as potential instruments that can be used to fuel the problems of insurgency and terrorism in Nigeria. In the words of a key informant:

There is a direct correlation between transnational street begging and terrorism. Their (transnational beggars) presence has added to the security challenges facing this country (Nigeria). These people usually come into the country as if their mission is peaceful, but on their arrival, they are always mobilised by fanatics to engage in nefarious activities because of their poor economic status. For instance, since the emergence of the BokoHaram problem, close to $3,000-4,000$ of them have been deported to their countries. (Police Officer/KII/Sango Police Station, Ibadan)

In the words of another respondent:

Security wise, the influx of transnational organised street beggars may constitute threat to the peaceful co-existence of Nigeria. They are foreigners who have nothing at stake and thus, 
can afford to do anything, because they have no family name to protect here (Nigeria). (Custom Officer/KII/Oyo/Osun Area Command, Ibadan)

Another respondent stated:

Actually, the current security challenges in the country have been linked to them (transnational organised street beggars). Most of them are linked to Boko Haram and other terrorist organisations. (Immigration Officer/KII/Zone ' $F$ ' Headquarter, Ibadan)

It can be inferred from these narratives that transnational organised street beggars soliciting alms in Nigeria were considered threatening to the peaceful and corporate existence of the nation because some of them have been identified as members of the Boko Haram insurgent group by law enforcement agents. This group of beggars may find it easy to engage in acts that are inimical to the existence of Nigeria because they are foreigners who have little or nothing at stake. This finding equally supports the observations of Azam (2011) and Salaheddin (2011) that suicide bombers have, in recent times, continued to disguise as beggars to gain access to some highly valued sites to detonate bombs and/or explosives. Equally, Bambale (2008), Yau (2000) and Olaniyi (2009) have also decried the roles that street beggars usually play in times of riots and civil unrests in Nigeria.

Transnational organised street beggars in Nigeria were also identified as contributing to crime occurrence. All the key informants maintained that this category of beggars routinely get involved in some criminal activities, such as trafficking in drugs, arms and ammunitions, armed banditry, thuggery, mugging, kidnapping and prostitution, among others. One of the respondents stated that:

It is not uncommon to find foreigners, who purportedly came into Nigeria to solicit alms or beg engaging in criminal activities. Transnational street beggars are prone to violence, and records have shown that they now engage in a whole lot of negative activities in active collaboration with some Nigerian criminals. They engage in thuggery, mugging, and kidnapping, amongst others. (Principal Officer/KII/Oyo State Ministry of Women Affairs, Community Development and Social Welfare)

In the words of another respondent:

Most of them do a lot of funny things apart from their street begging. They are involved in criminal activities like prostitution, thuggery and armed banditry; this is why there is a very high criminal activity in the border areas of the country. Some Nigerians also pay them a token, as little as $\$ 1,000.00$ (\$2) to perpetrate criminal act. For instance, in Benue State, due 
to their involvement in criminal activities, the State Government requested the service of the Nigeria Immigration Service to raid them, in which close to 2,000 of them were deported to their countries. (Police Officer/KII/Sango Police Station, Ibadan)

Another respondent corroborated further:

Some of them can be criminals. Begging can be used as an avenue to commit crime because they are always obstructing traffic. They have opportunity to do all sort of things. They can threaten one's life with guns and collect one's car at night. When I was at the border station, my Area Comptroller would always tell me to search any physically challenged person on a wheel chair very well. We did that at the Idi-Iroko and Seme border posts several times and discovered many pistols and live ammunitions. In fact, a beggar that we have been sympathising with for many years, and usually allowed to enter Nigeria was in the process discovered to have been supplying arms and ammunitions to criminals at border stations. (Custom Officer) KII/ Oyo/Osun Area Command, Ibadan)

It can be deduced from these findings that begging in general, and transnational organised street begging in particular, can serve as an avenue for perpetrating a wide range of criminal activities. It was revealed that some supposedly transnational street beggars coming to Nigeria to solicit alms have been caught several times by officials of the Nigeria Custom Service at the border posts while trying to smuggle arms and ammunitions into Nigeria from Benin Republic. Also, the reference made to the incident in Benue State in the North Central Nigeria where about 2,000 migrant street beggars were deported to their countries of origin because of their involvement in crime clearly reveals the criminal dimension of transnational organised street begging. Adedibu \& Jelili (2011), Alawi (2011) and Cheng \& Kumar (2012) have also maintained that street begging might be a cover for perpetrating some other criminal activities.

Furthermore, transnational organised street beggars were also recognised as contributing to the growing problem of population increase and its attendant over-stretching of some essential public facilities in most of the major urban centres in Nigeria. In addition, transnational organised street beggars, together with their local counterparts, according to the key informants, also constitute an economic burden to Nigerians because they are essentially dependent on people for their livelihood. One of the key informants submitted thus:

Whether formally or informally, the Nigerian Government is usually forced to make provisions for these transnational street beggars. They are more or less, a burden to the Government. 
(Principal Officer/KII/Oyo State Ministry of Women Affairs, Community Development and Social Welfare)

Another respondent observed thus:

The presence of transnational street beggars in Nigeria further adds to the burden of the Nigerian populace, directly or indirectly. (Police Officer/KII/Sango Police Station, Ibadan)

It can be deduced from the above narratives that transnational organised street beggars were seen as adding to the financial burden of Nigerians. Apart from the fact that their presence in Nigeria directly contributes to the overstretching of some public facilities, transnational organised street beggars, like their local counterparts, were also seen to be a source of financial burden to the citizens on whose goodwill they depend for their livelihood. This finding supports Adedibu's (1989) and Reddy's (2013) assertions that the higher the number of people involved in street begging, the heavier the economic burden on other members of the society.

Another way through which the influx of transnational organised street beggars constitutes threat to Nigeria is that their presence in the country can also lead to environmental and health problems. They were identified by the key informants to be potential carriers of viral infectious and contagious diseases capable of putting the health and physical well-beings of Nigerian citizenry at a risk. Similarly, they were also indicted as contributing to the defacement of the environment through their activities. In the words of a respondent:

When they (transnational street beggars) come to Nigeria enmasse like that, they may come into the country with some viral infections and other communicable diseases. Their presence also diminishes the aesthetic value and beauty of our city centres by creating unsavoury sights. They are always defacing the environment and consequently making it unappealing. (Principal Officer/KII/Oyo State Ministry of Women Affairs, Community Development and Social Welfare)

This finding is in consonance with Ndubuisi's (1986) and Salami \& Olugbayo's (2013) submissions that migrant beggars are potential carriers of communicable diseases from one country to another. Indeed, an unregulated cross-border movements have been identified as one of the major factors responsible for the recent spread of Ebola Virus Disease across some African countries (Aborisade, Adebayo \& Nnodim, 2014; Adepegba, Olokor \& Ajaja, 2014). Furthermore, this finding also confirms the submissions of Adedibu (1989) and Igbinovia (1991) that street beggars constitute social and environmental menace to the Nigerian society. 


\section{Conclusion}

This paper discussed border policing challenges and the consequences of transnational organised street begging in Nigeria. The porous nature of the Nigerian borders, the language affinity shared by the transnational organised street beggars with the people of northern Nigeria, human traffickers' activities, the lackadaisical posture of relevant government agencies towards the enforcement of the extant anti-street begging laws, as well as the ECOWAS policy on free movement were the major factors motivating the influx of transnational organised street beggars from some neighbouring African countries into Nigeria. Also, this group of beggars were recognised to be posing multiple problems to the wellbeing of Nigeria. Therefore, the following recommendations are considered germane to the effective curtailment of the problem. Firstly, there is the need for all relevant law enforcement agencies, particularly the Nigeria Immigration Service and the Nigeria Customs Service to review their strategies and develop effective frameworks through which illegal border entry of transnational organised street beggars can be combated through a result-oriented border policing.

Secondly, the Federal Government of Nigeria in conjunction with all relevant law enforcement agencies should develop an effective roadmap through which a holistic mapping of the geographical landscape of the Nigerian land-borders can be done to significantly address, if not totally eliminate, the perennial problem of porous borders. This step can go a long way in preventing undocumented migrant beggars from gaining entry into Nigeria illegally. Also, the personnel of the National Agency for the Prohibition of Trafficking in Persons and Other Related Matters (NAPTIP) should design far-reaching mechanisms through which the networks of human traffickers illegally bringing migrants into Nigeria for the purpose of alms solicitation can be adequately contained. Furthermore, the Federal Government of Nigeria should direct all relevant government agencies to include street begging in general, and transnational street begging in particular in their overall mandates. This step becomes imperative because transnational organised street beggars will find it difficult to solicit alms in Nigeria if begging by their local counterparts is not condoned. Finally, there is the need for the management of the Nigeria Immigration Service to put in place necessary frameworks through which immigration officers stationed at borderposts can be trained by linguists. It is believed that this step will equip them with the techniques through which they can effectively differentiate between the native Hausa speakers and the non-Nigerian speakers of the language as a way of addressing the language affinity factor that some transnational organised street beggars are banking upon to illegally gain entry into Nigeria. 


\section{References}

Abdullahi, R. (2016, April 14) Bill banning street begging, hawking passed in Kaduna state. Leadership.

Aborisade, S., Adebayo, B. \& Nnodim, O. (2014, August, 13) Ebola: FG bans inter-state movement of corpses. Punch.

Addo, P. (2006) Cross-border criminal activities in West Africa: options for effective responses. KAIPTC Paper, 12.

Adedibu, A.A. (1989) Begging and poverty in third world cities: a case study of Ilorin, Nigeria. Ilorin Journal of Business and Social Sciences, 1: 25-40.

Adedibu, A.A. \& Jelili, M.O. (2011) Package for controlling street begging and rehabilitating beggars and the physically challenged in Nigeria: paper for policy consideration. Global Journal of Human-Social Science Research, 11(1): 17-24.

Adedibu, A.A. \& Jelili, M.O. (2012) Characteristics and types of beggars in Nigerian cities: implications for public policy. Centerepoint Humanities Edition, 14(1): 144-167.

Adedokun, O.A. (2003) The rights of migrant workers and members of their families: Nigeria. International migration and multicultural policies section. UNESCO series of country reports in the ramification of the UN convention on migrants.

Adepegba, A. (2012, February 27) FG deports 7,000 over Boko Haram bombings. Punch, pp. 27.

Adepegba, A. (2013, February, 6) Immigration uncovers 1,487 illegal routes to Nigeria. Punch.

Adepegba, A., Olokor, F. \& Ajaja, T. (2014, August, 2) Ebola: Nigeria's 1,479 illegal borders may spread virus. Punch.

Adetula, V. (2015) Nigeria's response to transnational organised crime and jihadist activities in West Africa. Friedrich Ebert Stiftund Discussion Paper, x: 1-32.

Adewuyi, S.A. (2000) Socio-cultural determinants of street begging in northern Nigeria: the case of Sokoto. Ph.D. Thesis. Dept. of Sociology. University of Ibadan.

Adeyinka, A.M. (2014) Trans-border movement and trading activities across Nigeria- Benin Republic border. Mediterranean Journal of Social Sciences, 5(1): 415-423.

African Union (2012) Draft African Union strategy for enhancing border management in Africa. African Union Border Program, Ethiopia.

Afolayan, A.A. (1988) Immigration and expulsion of ECOWAS aliens in Nigeria. International Migration Review, 22(1): 4-27.

Alawi, I. (2011, January, 20) Beggars, prostitutes arrested in Jeddah. The Saudi Gazette. Retrieved from http://www.saudigazette.com.sa/index.cfm?Method=home.regcon\&content $=2011012091711$.

Alli, Y. (2016, December 28) Army arrests 40 foreigners after Sambisa forest's fall. The Nation. 
Annuska, D. (1998) Reintegration of victims of trafficking in Cambodia. International Organization for Migration and Centre for Advanced Study.

Balogun, A. (2012, March 17) New forms of begging on Lagos streets. Saturday Punch.

Bambale, J. (2008) Almajiranchi and the problem of begging in Kano state: the role of Shekarau administration (2003-2007). Paper presented at the 7th Ben-Africa Annual Conference, Addis Ababa, Ethiopia.

Blum, C. (2014) Cross-Border Flows between Nigeria and Benin Republic are the challenges for (human) security? Friedrich-Ebert-Stiftung, Abuja, Nigeria.

Cheng, S.C. \& Kumar, V. (2012) Pattern of exploitation and organised crime: a study on homeless beggars in Patna, Bihar. International Journal of Scientific and Research Publications, 2(11): 1-5.

Cherneva, I. (2011) Trafficking for begging: old game, new name. Amazon Books.

Clarke, R.V. (1992) Introduction. In R.V. Clarke (Ed.). Situational Crime Prevention: Successful Case Studies. Albany, NY: Harrow and Heston. pp. 5-9.

Clarke, R.V. (1983) Situational crime prevention: its theoretical basis and practical scope. Crime and Justice, 4, 225-256.

Delap, E. (2009) Begging for change. Research findings and recommendations on forced child begging in Albania/Greece, India and Senegal. AntiSlavery International.

Friends-International and United Nations Inter-Agency Project (2006) The nature and scope of foreign child beggars issue (especially as related to Cambodian child beggars) in Bangkok. United Nations Inter-Agency Project to Combat Human Trafficking in the Greater Mekong Sub-Region.

Igbinovia, P.E. (1991) Begging in Nigeria. International Journal of Offender Therapy and Comparative Criminology, 35(1): 21-33.

International Organisation for Migration (2004) Changing patterns and trends of trafficking in persons in the Balkan region. IOM, Counter-Trafficking Service, Geneva.

Invernizzi, A. (2011) Vulnerability to exploitation and trafficking of Bulgarian children and adolescents in Greece. OAK Foundation.

Lamptey, A.A. (2013) Rethinking border management strategies in West Africa: experiences from the Sahel. Kofi Annan International Peacekeeping Training Centre Policy Brief, 12.

Kayode, B. (2017) Army arrested 26 Nigeriens, Chadians for aiding Boko Haram. Nigerian Tribune, Feb. 3.

Koselci, N., Rosati, F. and Tovo, M. (2007) Measuring the worst forms of child labour: The case of begging children in Dakar. World Bank. 
Mehak, M. (2012) Street begging in Delhi: a study of anti-begging act and institutional arrangements for homeless people. Researching Reality Summer Internship Working Paper. Centre for Civil Society.

Miller, M.J. (2001) The sanctioning of unauthorized migration and alien employment. In D. Kyle \& R. Koslowski (Eds.). Global human smuggling. Comparative perspectives, Baltimore, MD: Johns Hopkins University Press, pp. 318-36.

Muhammed, U. (2016, June 10) Nasarawa Govt. bans street begging. Punch.

Ndubuisi, F. (1986, June 27) Begging, a way of life. Punch, pp. 5.

Ogunkan, D.V. \& Fawole, A.O. (2009) Incidence and socio-economic dimensions of begging in Nigeria Cities: the case of Ogbomoso. International NGO Journal, 4(12): 489-503.

Ojedokun, U.A. \& Aderinto, A.A. (2015) Migratory trajectory of transnational street beggars in South Western Nigeria. Ibadan Journal of the Social Sciences, 13(1): 27- 43.

Okoli, I. (2013, March 23) Boko Haram: police arrest 500 foreigners in Lagos. Vanguard.

Okumu, W. (2009) Border security in Africa. Paper presented at the African Union border programme regional workshop, Windhoek, Namibia.

Olaniyi, R. (2009) Economic crises and child trafficking in Nigeria: a comparative of the 1930s and 1940s. Retrieved from http://www.codesria.org/IMG/pdf/chap4.pdf.

Reddy, S.C. (2013) Begging and its mosaic dimensions: some preliminary observation in Kadapa district of Andhra Pradesh. Afro Asian Journal of Social Sciences, 4(1): 1-31.

Salaheddin, S. (2011, September 2) Baghdad mosque suicide bomber disguised self as beggar. Huffington Post. Retrieved from http://www.huffingtonpost.com/2011/08/29/baghdad-mosque-suicide-bomber_n_940072.html.

Salami, K.K. \& Olugbayo, A. (2013) Health-seeking behavior of migrant beggars in Ibadan, Southwestern Nigeria. Health, 5(4): 792-804.

Social Development Notes (2009) Human trafficking: a brief overview. Conflict, Crime and Violence, 122: 1-16.

Punch (2012, January 9) Nigerian Beggars Arrested in Ghana, Deported. pp. 9.

UK Border Agency (2010) Protecting our border, protecting the public. UK Border Agency.

Vanguard (2013, February 7) Nigeria's porous borders.

Väyrynen, R. (2003) Illegal immigration, human trafficking, and organized crime. United Nations University Discussion Paper, 72.

West Africa Network for Peace-Building (2013, March 25) Is the African giant drowning but not waving? - exploring a coordinated approach to the Nigerian security challenges. WARN Policy Brief, 25.

Yau, Y. (2001) The youth, economic crises and identity transformation: the case study of Yandaba in Kano. In A. Jega (Ed.). Identity transformation and identity politics under structural adjustment in Nigeria, Nordiskan 
African Institutet and Centre for Research and Documentation, pp. 178199. 